\title{
The Emergence of a Modern Audience for Cinema in Colonial Java
}

\author{
Dafna Ruppin \\ Institute for Cultural Inquiry (ICON), Utrecht University \\ D.Ruppin@uu.nl
}

\begin{abstract}
This article examines the emergence of a modern audience for early cinema in colonial Java at the beginning of the twentieth century. As a visual medium combined with musical accompaniment, moving pictures were suitable for a wide range of audiences. The melange of cinema-goers studied here reflects the plurality of dialects, ethnicities, and social classes in colonial society. This article explores what brought audiences on Java to spend their leisure time at the cinema, the films they watched, and how the spatial separation between different classes of audience members was arranged, upheld, and, at times, transgressed at the various venues that exhibited moving pictures. Finally, it argues that going to the cinema provided audiences with an education in modern things, whether in the content of films representing modernization, progress, industry, and urbanization, or in the form of encountering the technology itself and of patronizing the increasingly modern venues that housed them.
\end{abstract}

\section{Keywords}

colonial Java - early cinema - Indonesia - cinema-going - class - ethnicity - gender modernity

In 1905, a mere decade after moving pictures first arrived in colonial Java, a Dutch newspaper report from Buitenzorg (Bogor) revealed how popular this modern entertainment form had become among urban residents of the Indonesian archipelago. Under the heading 'Cinemania', it further alluded to a whole host of class, racial, and gender concerns surrounding the social practice of cinema-going in a colonial society:

(C) DAFNA RUPPIN, 2017 | DOI: 10.1163/22134379-17304014

This is an open access article distributed under the terms of the prevailing CC-BY-NC license at the time of publication. 
Everything here revolves around the cinema. They get together at the bar of the Royal [Bioscope]. Young girls are constantly flirting in the evening dusk of the cinema. Natives steal, and if they are caught they excuse themselves by saying that they had no money to go to the cinema. A father [...] complains that his daughter has disappeared; last night she went to the cinema and since then she has been missing. [...] Employees ask for advance payment no longer because their father or mother has passed away - I had a stable boy who lost seven mothers - but because they want to go to the cinema. We are smothered by the heat of the day and look forward filled with hope to the clouds, [...] [but] then there is always someone who says: 'I still hope that the evening remains dry, otherwise we can't go to the cinema.' Even the washer man [...] lends white pants and jackets to unfortunate native dandies who also want to go to the cinema in style $[$ chic $] .[\ldots]$ The owners [...] make a fortune with their cinema. And if in the beginning of the month a lady moans because her hubby is so tight with his household budget, the man says: 'Yes, we have to set aside some money for the cinema.' ${ }^{1}$

As a visual medium combined with musical accompaniment, moving-picture technology had the potential of instantly appealing to a wide range of audiences, reaching far beyond its points of origin in the West in the final years of the nineteenth century. European men with (or without) their wives and/or children, middle-income Javanese families, Chinese stall owners and single Chinese women, Eurasian office workers, drunken soldiers and sailors, and orphaned children, among others: all swarmed into canvas and bamboo tents or palatial cinemas built out of brick and stone located in Java's main city squares (Fig. 1).

This article examines the emergence of this modern audience for moving pictures in colonial Java in the early twentieth century by drawing on contemporary reports in Dutch- and Malay-language newspapers, government documents, travelogues, guidebooks, and archival maps and photographs. ${ }^{2}$ It

1 Het Nieuws van den Dag voor Nederlandsch-Indië, 12-10-1905. All translations from Dutch and Malay are my own, unless otherwise stated. The findings presented in this article form part of the research project 'The Nation and Its Other: The Emergence of Modern Popular Imagery and Representations', which was funded by the Netherlands Organisation for Scientific Research (Nwo).

2 The research approach here is in line with the 'new cinema history', a methodology which since the 199os has shifted the focus in the writing of cinema history 'away from the content of films to consider their circulation and consumption, and to examine the cinema as a site 


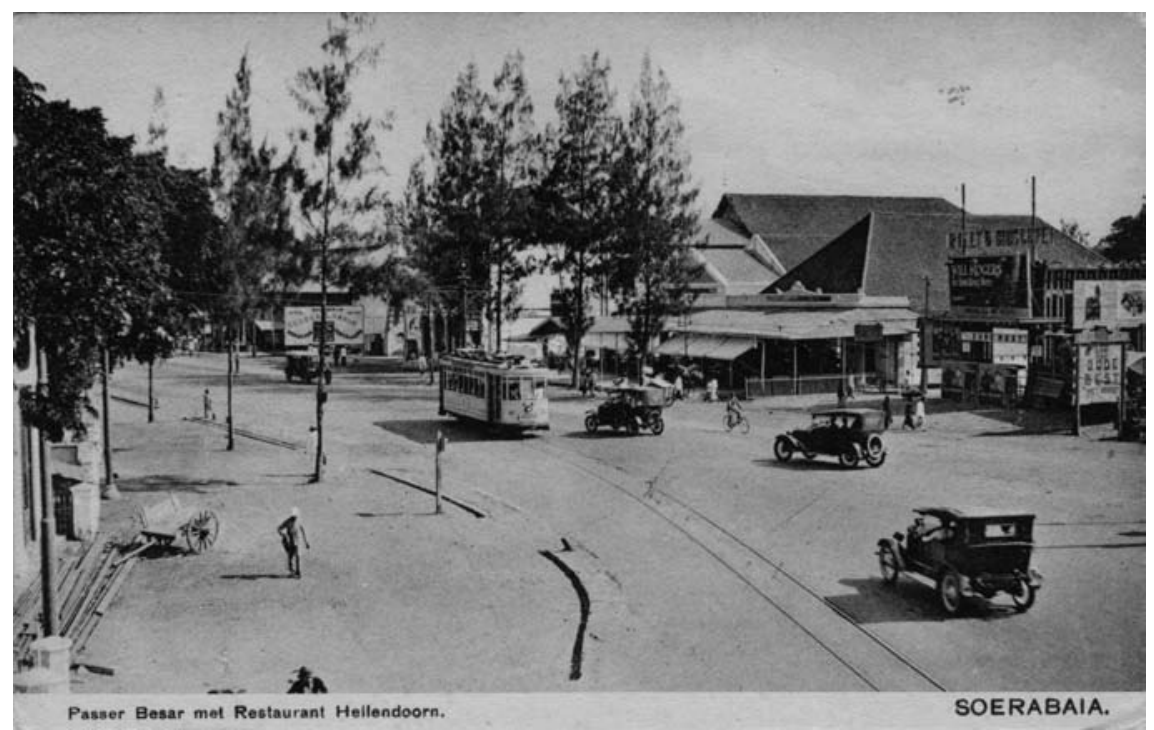

FIGURE 1 Image of Pasar Besar in Surabaya c. 1920, showing a restaurant and cinema and a busy road full of cars, bicycles, trams, and pedestrians PHOTO BY G.C.T. VAN DORP \& CO., C. 1920. COURTESY OF LEIDEN UNIVERSITY LIBRARY, IMAGE CODE 1404493

explores what brought audiences on Java to spend their leisure time at the cinema, the films they watched, and how the spatial separation between different classes of audience members was arranged, upheld, and, at times, transgressed at various venues for exhibiting moving pictures. By focusing on the intersection of class, ethnicity, and gender at the cinema, a social institution which has been largely overlooked in previous studies of everyday life in urban colonial Java, it aims to investigate the tensions between, and shifts within, these categories. $^{3}$

of social and cultural exchange' (Maltby 2011:3). Cinema-goers are perceived as social actors who are actively engaged with the films they watch and with other audience members. Their experiences must therefore be understood as bounded by 'specific social, cultural, historical and spatial confines' (Biltereyst, Maltby and Meers 2012:2).

3 It is therefore in agreement with recent scholarship showing that ethnicity, understood in racial terms, is not the only category that should be considered when studying the history of colonial society. As Khusyairi and Colombijn (2015:253) note in their study of the modernization of transportation in Surabaya in the 1920s, while 'ethnicity was very important and racial discrimination visible in many places, $[\ldots]$ in some aspects of colonial society [...] a focus on income rather than ethnicity gives more insight in the social dynamics'. See also Colombijn's work on housing (Colombijn 2010). 
In his seminal work An age in motion, Takashi Shiraishi (1990) noted that the indigenous class of young students, graduating with Western-style educations under the Ethical Policy and taking up salaried, middle-class jobs in urban areas, typically mixed Dutch words into their everyday conversations, opted for Western-style clothing, went out to restaurants, enjoyed new musical styles, and watched films. Yet, beyond such passing mention of cinema-going as a pastime activity of the indigenous middle classes, Shiraishi does not discuss the cinema, or what impact it might have had on residents of the Indies in the first quarter of the twentieth century, or the 'modern age' in the life of the colony (Shiraishi 1990:27).

As the present research has discovered, at the turn of the century, itinerant exhibitors of myriad nationalities toured Java via steamship and railway with various devices for exhibiting moving pictures. ${ }^{4}$ Shipped into Java on nearly a weekly basis from Europe or the United States, moving pictures brought images from the streets of Paris and Vienna, vivid impressions of current events, as well as comedies and dramas to audiences from all levels of colonial society, almost simultaneously with these developments in the rest of the world. Occasionally, programmes were further supplemented by local footage captured by local cameramen, depicting local festivals and customs alongside scenes of development and progress, showing tramways, steamships, and modern industry on Java. Scenes of modern life-from Java, and from the greater world outside it - along with the advanced state of infrastructure at many cinemas provided urban cinema-goers on Java with a sense that they were on a par with the great metropoles of Europe. With moving pictures able to bridge language and literacy gaps, audiences on Java were thus participating in an 'imagined community', potentially far greater than Benedict Anderson's (2006 [1983]) conceptualization of the term in connection with the advent of print capitalism. They were not only forming bonds with anonymous cinema-goers attending the same venue, or even with audiences flocking to cinemas in other parts of Java, but also with individuals from Paris, London, and other parts of the globe who, as advertisements and promotional pieces informed them, were similarly drawn to this new technology and consuming the same images.

4 In fact, while the technology of moving pictures and most of the films shown at the time originated from the West, many of the exhibitors found in this research were themselves Asian. Out of those identified as European, only a handful were Dutch. This supports Elsbeth LocherScholten's (2000:34) claim that modernity arrived in twentieth-century colonial Indonesia from many different directions, and not only via the colonizer. See also Nadi Tofighian's (2013:90-3) discussion of moving-picture technology disseminated by Asian exhibitors in Southeast Asia. 
This article first provides an overview of the various locations and contexts in which moving pictures were exhibited to audiences in colonial Java at the turn of the century. It then portrays the viewing conditions at temporary and fixed moving-picture venues and the various spectatorial positions fashioned by them in an effort to observe how class, race, and gender criss-crossed and intertwined to influence audiences' cinema-going experiences. Finally, it examines some of the content of moving-picture programmes and considers how these might have challenged ideas about race, class, and gender in colonial society. Throughout, film audiences in colonial Java will be viewed as 'cultural citizens' of the colony (Schulte Nordholt 2015). As Henk Schulte Nordholt argues in his study of 193os' advertisements and school posters targeting the indigenous elite and middle classes, although these individuals were denied political power and many civil rights, through 'educational programmes and commercial advertisements' they were, nevertheless, 'explicitly invited to abandon traditional habits and to become the new cultural citizens of the colony' (Schulte Nordholt 2015:228-9). Embracing a modern lifestyle, Schulte Nordholt argues, worked in turn to reinforce the interests of the colonial regime, especially since the majority of indigenous students who were the products of this system ended up working for the government.

Moving-picture shows, the most modern form of entertainment available at the time, neatly fitted with such a pursuit of modern things. ${ }^{5}$ Moving-picture technology was at first described by contemporary commentators on Java as an innovation or invention of 'modern science' (Java-Bode, 4-3-1897 [in Dutch]) or as something that is 'new' to people in the Indies (Bintang Barat, 8-3-1897 [in Malay]), suggesting that modernity was identified in both cases as something novel and innovative. ${ }^{6}$ By the 1910s, the topics of films screened, mostly originating from France, Britain, or the United States, were described as 'modern' (Soerabaiasch-Handelsblad, 8-11-1910); one would, for instance, encounter

5 I am guided by Frederick Cooper's (2005:131) call to researchers to look for a 'discourse of modernity' and to think about how and why it is being used. Cooper (2005:115) argues that, rather than trying to find a 'better definition' for talking about modernity, scholars should try to identify a 'discourse of modernity' in order to see how modernity is manifested and experienced in different contexts.

6 It is crucial to examine and compare the language used in Dutch and Malay texts. As Vickers (1996:5) warns: the 'modern/moderen involves processes of translation, finding similarities. In Indonesian the connected ideas of progress/kemajuan, development/pembangunan and individual achievement/budi - along with a series of linked terms - are in fact fundamentally different terms from their English versions, involving radically different perceptions'. 


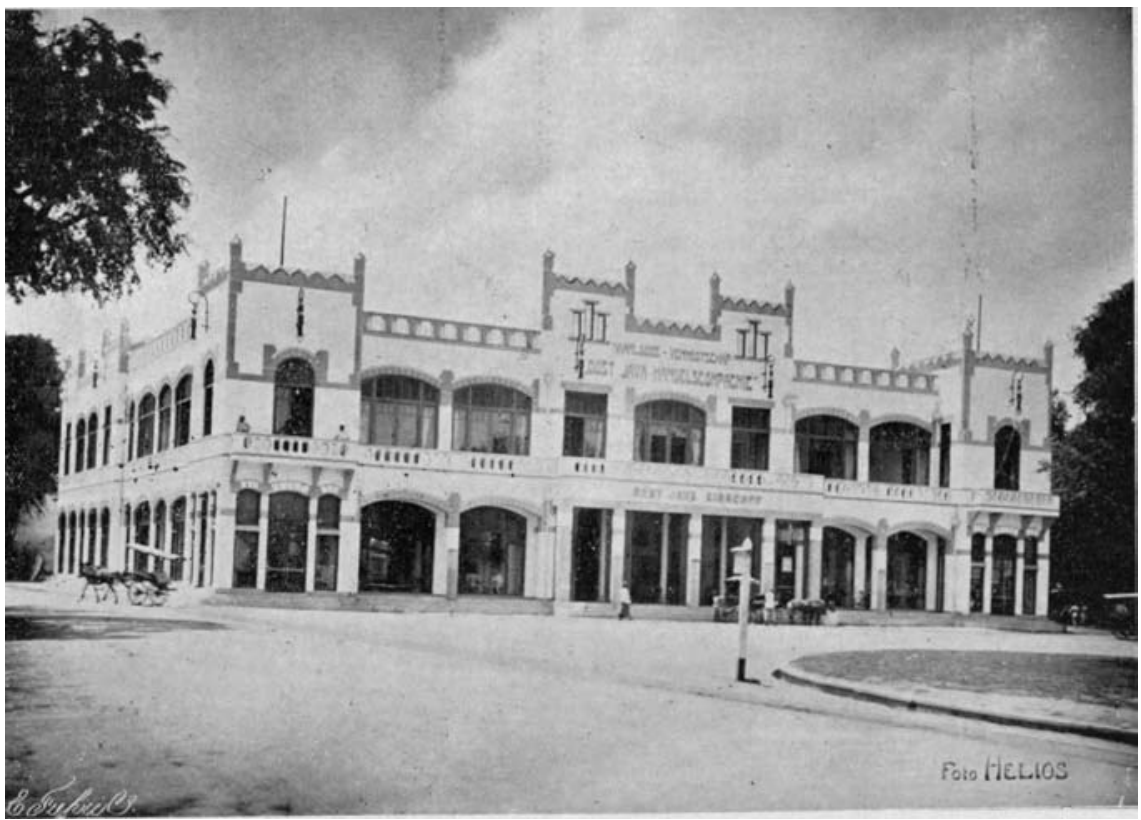

FIGURE 2 Image of the exterior of the East Java Bioscope in Surabaya, c. 1913, the first cinema palace built on Java

WEEKBLAD VOOR INDIË, 30-11-1913

phrases such as 'modern films' (Soerabaiasch-Handelsblad, 23-3-1914), 'modern dramas' (Het Nieuws van den Dag voor Nederlandsch-Indië, 15-6-1914), and 'a modern morality drama' (Soerabaiasch-Handelsblad, 1-12-1914). 'Modernity' was thus evoked in the sense of something contemporary, of the time, which did away with tradition (Java-Bode, 29-9-19o8; Taman Sari, 17-7-19o8; Soerabaiasch-Handelsblad, 30-3-1910). Furthermore, the word 'modern' was commonly applied in the description of venues, thus introducing an aesthetic dimension, especially as cinemas became more permanent and were built out of brick and stone in the early 1910s (see Figures 2, 3, and 4 of the East Java Bioscope). A cinema was judged to be modern if it met 'modern demands' (Java-Bode, 6-10-1910), when it was 'built in the modern style' (Nieuwe Soerabaja Courant, 24-1-1912), as a 'modern and beautifully finished stone cinema building' (Nieuwe Soerabaja Courant, 15-1-1912), with a 'modern décor' (Bataviaasch Nieuwsblad, 3-7-1912) and 'modern façade that befits [a] new cinema building' (Soerabaiasch-Handelsblad, 23-9-1912), and with an interior arrangement that was 'so modern and so comfortable' (Soerabaiasch-Handelsblad, 279-1912) with the 'highest modern furnishing' and 'modern cinema installation' (De Locomotief, 16-12-1912). 


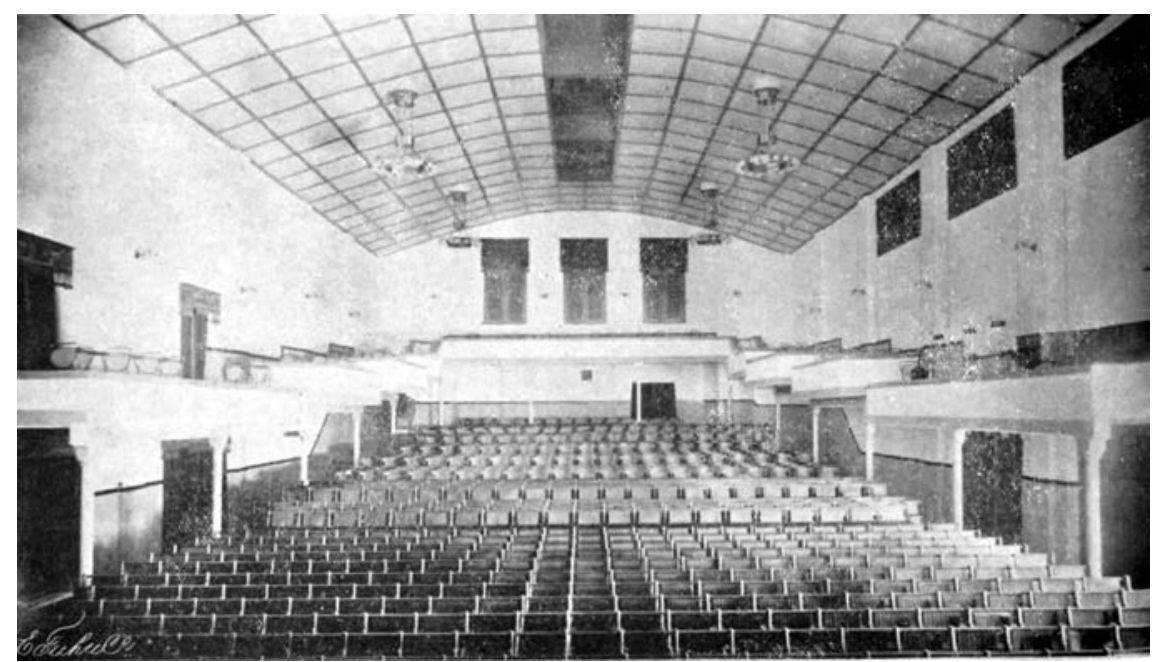

FIGURE 3 Image of the interior of the East Java Bioscope in Surabaya, c. 1913 WEEKBLAD VOOR INDI ̈̈, 7-12-1913

Most interestingly within the context of 'cultural citizenship', the cinema was often viewed as a 'modern learning source' (De Locomotief, 2-10-1908), with a positive value judgement. ${ }^{7}$ Early exhibitors of moving pictures in fact often tapped into the discourse of education and progress promulgated by the Ethical Policy, either by offering free shows to soldiers or orphans, or by screening educational films about hygiene, production processes, and industry. ${ }^{8}$ This served, at the same time, as a tactic for placating any concerns of the colonial authorities about the potential negative effects of watching films. To extend Schulte Nordholt's use of 'cultural citizenship' to cinema audiences, then, moving pictures in this view would be perceived as modern tools of 'public education' (Pleyte 1907:6). And whereas elitist colonial schools were only accessible to a certain elite class of society, cinema-going was available to individuals of all ages and from all levels of colonial society. It provided audiences with an education in modern things, whether in the content of films representing modernization, progress, industry, and urbanization, or in the form of encountering the technology itself and of patronizing the increasingly modern

7 Conversely, cinema was frequently, and with even more urgency, described as a source of negative influence in 'the "modern" manner' (Nieuwe Soerabaja Courant, 10-2-1910).

8 While cinema would later be used in the service of colonial objectives, such as education about hygiene, moving pictures' pedagogical potential was largely unrealized by the colonial authorities in the period under scrutiny; see Stein 2006 on 1930s' hygiene promotion films in Java. 


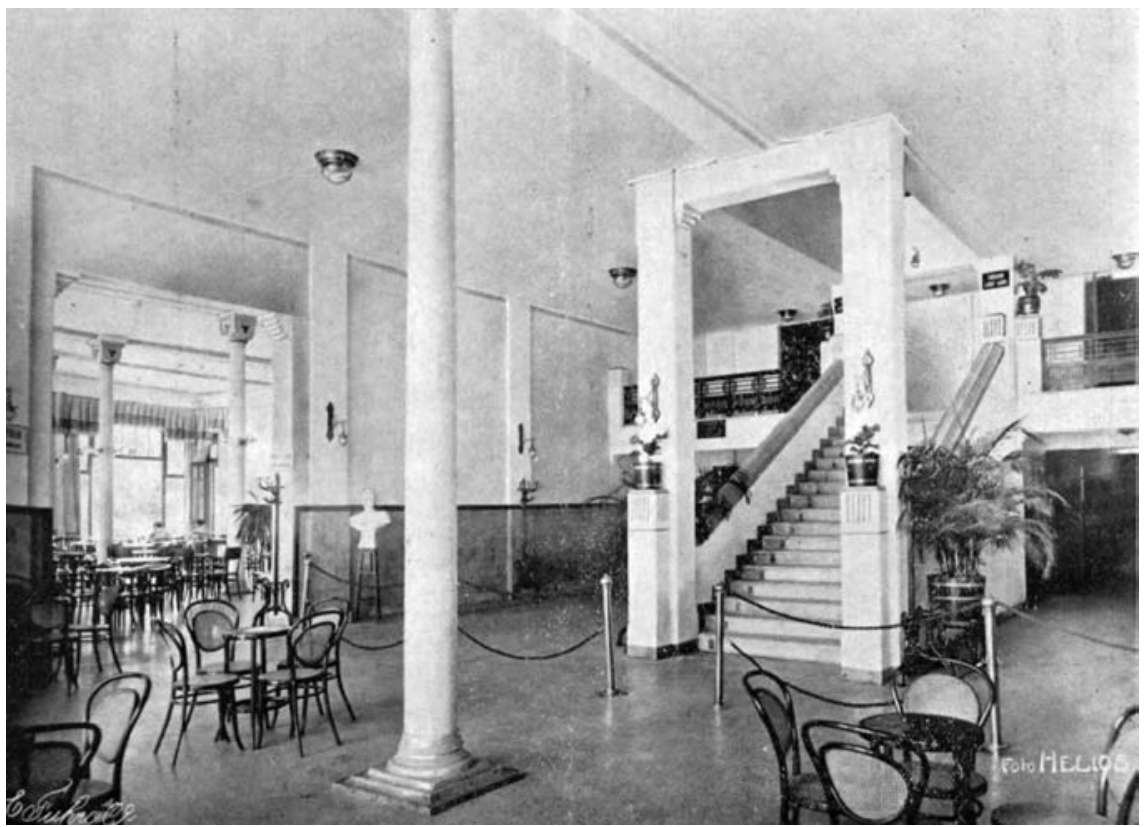

FIGURE 4 Image of the interior of the East Java Bioscope in Surabaya, c. 1913 WEEKBLAD VOOR INDIË, 7-12-1913

venues that housed them. By watching film programmes mostly consisting of films imported from the West, exposing them to modern and desirable lifestyles on screen, audiences from all levels of colonial society were to be set 'in motion' (Shiraishi 1990) at Java's cinemas.

\section{“"Waaa...h!" Sounds Rise from Behind the Screen': Class, Ethnicity and Spectatorial Position}

Moving-picture shows first arrived in colonial Java in October 1896 ( Java-Bode, 9-10-1896) - just ten months after the celebrated Lumière brothers' first screenings with their Cinèmatographe in Paris in December $1895 .{ }^{9}$ While shows were

9 Anthologies of early cinema history in general, and of the history of cinema in Indonesia in particular, previously set the starting date for cinema in the region as December 1900 (Abdullah et al 1993; Ardan 2005:320; Biran 2009). Edison's Kinetoscope, a peephole device for viewing moving images individually, was displayed even earlier, in 1896 (Java-Bode, 19-81896). For more on the arrival of moving pictures in colonial Indonesia, see Ruppin 2016. 
initially performed only at European-style theatres or clubhouses, presumably attracting mostly European audiences as well as members of the Chinese and indigenous elite classes, by early 1897 the new technology had already moved to venues attended by a wider range of viewers. Moving pictures were screened at theatres in the Chinese kampung and in canvas tents set up in town squares. They were further incorporated into other popular amusements, for instance, on the grounds of the popular Harmston's Circus, or as part of the Victoria Parsi Theatrical Company's shows. As of 1905, moving pictures were also a regular fixture of pasar malam and Pasar Gambir entertainments. ${ }^{10}$ Moreover, while the earliest shows were offered at a premium price of $f$ 1.00 or even $f_{2}$.oo per ticket, the shows that followed introduced cheaper tickets at a quarter of the price, thus making cinema-going an affordable option for a larger number of audiences in Java's port cities and inland towns." ${ }^{11}$

As of the turn of the century, tickets for moving-picture shows were available in different pricing and seating categories, with the cheapest tickets, explicitly offered to 'Natives', priced at $f \circ .25$ and continually dropping to $f \circ .15$ and $f$ o.10; sometimes tickets were even as cheap as $f \circ .02 .{ }^{12}$ At times, separate tickets were also offered to 'Foreign Orientals'. Pricing categories at moving-picture venues thus reflected the racial classification employed by the Dutch colonial administration, which generally split the population of the Netherlands Indies into three groups: 'Europeans' (Europeanen), 'Natives' (Inlanders), and 'Foreign Orientals' (Vreemde Oosterlingen). ${ }^{13}$ Yet, significantly, cinema tickets for Euro-

The public fairs also served as topics to be filmed, often captured by the same companies that were exhibiting moving pictures at these fairs. Films of these fairs were then often screened to audiences at the same fair, and subsequently shown in other towns, as exhibitors progressed on their tour of Java.

11 To put the ticket prices of moving-picture shows into context, even at the early novelty stage admission was in the same price range as other entertainments on Java, such as magic shows ( $f_{0}$.50 to $f_{1.5}$; Java-Bode, 26-5-1897), panoramas ( $f_{0.25}$ to $f_{1}$; SemarangCourant, 24-10-1896), and tableaux vivants ( $f \circ .25$ to $f$ 2.50; Soerabaija-Courant, 9-4-1897). A visit to the circus would have usually cost $f_{4}$ for first-class seats, $f_{2}$ for second-class seats, $f_{1}$ for a bench seat, and $f$ o.5o in the gallery, which was reserved for Natives only-a pricing category which would be introduced by moving-pictures exhibitors more regularly in the early 19oos (Soerabaija-Courant, 15-6-1896).

12 Advertisements either used the markers 'Natives', 'Muslims', or 'Javanese' in reference to this pricing category.

13 These distinctions carried with them judicial implications, dictating one's place in colonial society. At the same time, while the classification system was supposedly rigid, there was still some fluidity within and between the categories (Fasseur 1994). In 1905, there were nearly 30 million 'Natives', 317,0oo 'Foreign Orientals', and about 65,000 'Europeans' 
peans always remained unmarked. The only instances in which advertisements addressed European audiences directly were to specify that Europeans would not be admitted to the section reserved for Natives. Even such venues occasionally abandoned this requirement, if the higher rank of seats were sold out. So it appears that some Europeans had no qualms about sitting next to Natives, as long as they could save a few cents in the process. This suggests that, at least to a certain extent, the practice denoted an economic or class-based differentiation rather than purely racial segregation. And while pricing categories clearly mirrored the racial mechanisms employed by the colonial authorities, it also shows that cinema-going was potentially available to all members of colonial society (see also Setijadi-Dunn and Barker 2010).

The auditorium space for Europeans in cinemas was definitely the section in which exhibitors invested the most effort and money to make it comfortable, inviting, and modern. For example, the Nederlandsch-Indische Biograph Compagnie (Netherlands Indies Biograph Company) apparently turned the trumpet of the gramophone used to accompany the show towards the more expensive seats in its touring canvas tent (Soerabaiasch-Handelsblad, 20-7-1905). The interior of the Chinese-owned iron structure of the Sirene Bioscope in Surabaya was decorated with green-coloured wallpaper in the section intended for Europeans and was equipped with electric lighting and excellent ventilation (Nieuwe Soerabaja Courant, 10-9-19o9). And the upstairs balcon de luxe of Surabaya's East Java Bioscope provided a comfortable vantage point from which one had an unobstructed view of the screen and the audience in the hall (Weekblad voor Indië, 7-12-1913). Nevertheless, it is difficult to deconstruct the European category, since we do not know the exact number of Eurasians included in this class. ${ }^{14}$ Moreover, being European in the Indies did not necessarily denote that one was of a high economic or social status; colonial administrators, as Stoler (1989) shows, had long been concerned about 'poor whites' and 'pauperism' in their territories. It is therefore not surprising that some Europeans found the cheaper seats to be an attractive option.

The legal category of Native was similarly diversified, covering the entire spectrum of indigenous-born Indonesians, which included a variety of eth-

living in Java and Madura, making 'Europeans' just $0.22 \%$ of the total population, most of whom resided in the cities (Furnivall 2010 [1967]:347).

14 According to estimates around 1900, by the early twentieth century, $80 \%$ of the Dutch population of the colony had been born in the tropics, and an unspecified but large majority of them would have been of so-called mixed race, in most cases born to an Indonesian mother and a European father (Mrázek 2002:9). Of all the children that held Dutch citizenship born in the Indies, some $40 \%$ could not even speak Dutch. 
nicities and religious or cultural influences: Javanese, Madurese, Sundanese, Bugis, Dayaks, et cetera. Depending on the venue, seats for Natives would have either been in the upstairs gallery, right in front of the screen, in what became known as the kambing (literally: goat) class, or behind the screen. The latter layout would have been familiar to people on Java from the wayang kulit, where audiences were able to watch the show from both sides of the screen: either in front of the canvas, enjoying the shadow effect, or from behind the screen, watching the dalang working the puppets. Having looked through tens of thousands of metres of microfilm of Dutch and Malay newspapers from four major cities, from 1896 to 1918 , I have come across plenty of evidence that suggests that this latter arrangement was widely employed throughout the entire period and in many venues across Java. ${ }^{15}$ It is not clear when exactly this layout was first introduced in moving-picture tents, nor when it was abandoned, but it was so widespread that even the luxurious cinema of the East Java Bioscope in Surabaya, built in 1913 to accommodate $75^{\circ}$ Europeans and 400 Natives, offered cheaper seats for Native audience members behind the screen (Weekblad voor Indië, 30-11-1913).

An exceptional portrayal of this screening situation was provided by a reporter from Surabaya in late December 1904. Following a visit to the 'giant waterproof tent' of the Netherlands Indies Biograph Company, which could allegedly contain 2,500 people, he wrote an account titled 'An evening at the Biograph':

Boom, boom, boom ... Djing, djing ... A high-pitched flute combined with the sound of clashing cymbals, the bang of a big drum and wirrr, wirrr of the machine. The tent is naturally chock-full.

The natives sit open-mouthed gawking at the white screen in the middle. A shrill whistle announces that [the show] is about to begin. The electric arc lamps are turned off, the manager ascends to his booth. [...] $[\mathrm{T}]$ hen a bright circle appears which is immediately filled with a picture: the Kalimas at Goebeng [in Surabaya].

'Waa...h!' sounds rise from behind the screen, the section for the natives. When there are compelling scenes, these children of nature cannot

15 This arrangement was supposedly common in other parts in the region, such as British Malaya (see Bottomore 2005:590-1). However, Nadi Tofighian has told me in private communication that he has not found any such instances in his own research on Southeast Asia in this period. I take this as evidence that this arrangement was less prevalent outside the Netherlands Indies. 
control their emotions. When a sleepwalker [...] is about to fall down, a good soul, mortally terrified, calls out: 'Allah, tobat!' [Allah, have mercy, DR] Or when the little moon people come into battle with the earthlings who, à la Jules Verne, land on the moon, and evaporate into gas, they do not understand much, but that does not bother them: there is so much action in the most charming pictures, that the attention remains stimulated. [...]

The natives laugh themselves into seizures at the scenes with the enchanted clothes [...], while the white people shudder at the poignant depiction of the life of an actor, finally hung for committing murder [...]

Soerabaiasch-Handelsblad, 25-11-1904, emphasis added

This detailed description further illustrates the kind of films an audience on Java might have seen when attending moving-picture shows in this period. Film programmes of roughly an hour to an hour and a half in length were made up of a series of short films. These were comprised of non-fiction actualities-mostly of foreign origin but occasionally also filmed locally (as in the case above)as well as of imported comic and dramatic scenes, such as Georges Méliès's famous film Le voyage dans la lune (Méliès, 1902) as depicted here. ${ }^{16}$ Additional fiction titles, such as Bluebeard, Ali Baba and the forty thieves and other stories from the Arabian nights, and even a filmed version of Nyai Dasima, would have been recognizable to audiences from their earlier publication in Malay print, or even more widely familiar from their adaptations for the komedistambul stages (Ruppin 2016). It should also be noted that moving pictures were not viewed in silence. Aside for the clatter of the machine and the voices of other audience members, shows would have been accompanied by a gramophone playing a Western, Chinese, or Malay repertoire; a piano player or an automated musical device, such as an orchestrion (playing from a perforated music roll and intended to sound like a band or orchestra) or a pianola (a selfplaying piano worked by the player controlling the pneumatic mechanism); or a string orchestra or gamelan ensemble. Moreover, a lecturer commenting on the images would have often been present. In cases where the audience was seated on either side of the screen, it is possible that there were two lecturers.

By 1910, according to an account by a travelling exhibitor in the region published in the trade journal The Kinematograph, moving-picture exhibitions were mostly

16 For an overview of early film programming in the West, see Abel 2012. 


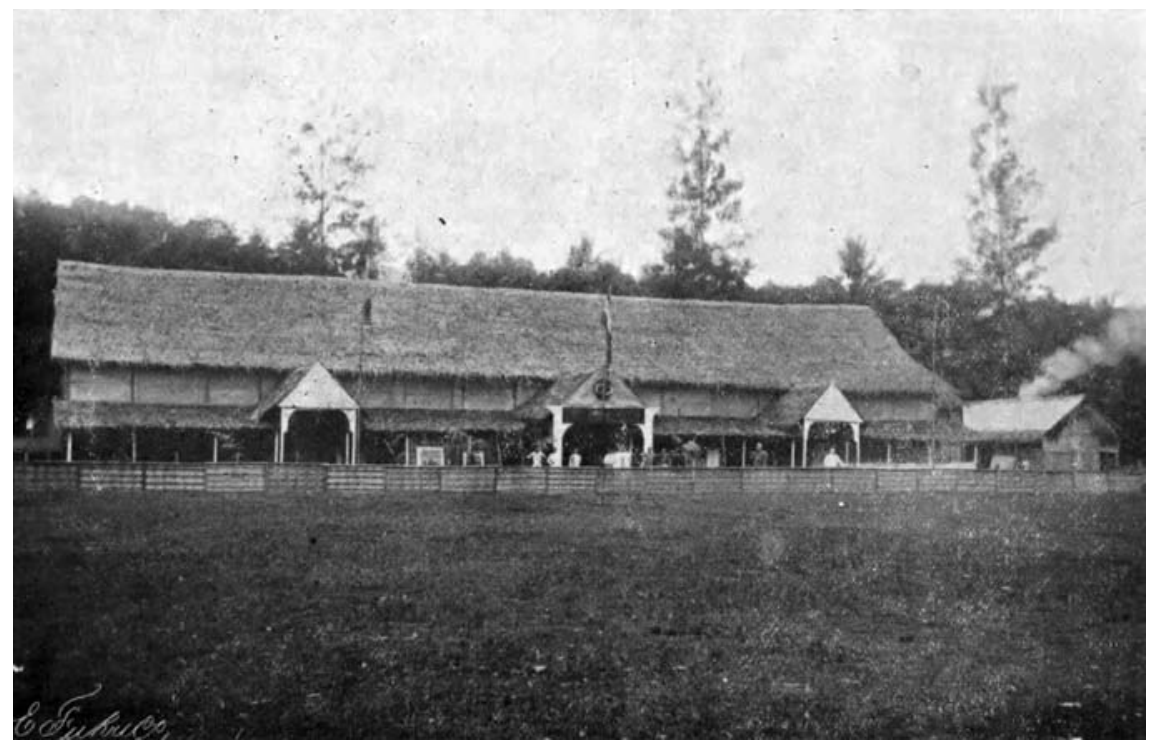

FIGURE 5 Image of East Java Bioscope's bamboo tent in Surabaya, c. 1912 WEEKBLAD VOOR INDIË, 30-11-1913

held in large well-built tents of canvas or bamboo and matting-not circular, but long and narrow on the lines of a hall and with no posts to obstruct the view. The management seems to spare no expense in making their 'houses' attractive and comfortable, and the approaches are richly carpetted [sic] and lined with banks of tropical plants. Most of them have their own electric light generators, and the entrances are a veritable blaze of light.

COULTER 1909:1039

Such venues, often described as a 'semi-permanent tent' (Nieuwe Soerabaja Courant, 11-9-19o8) or even a 'permanent tent' (Soerabaiasch-Handelsblad, 289-1908), sometimes stood for years in the same spot while the companies exhibiting the films would rotate every few months (see Fig. 5 for an example of such a structure).$^{17}$ Many of these companies performed shows two or three

17 See also Tofighian's (2013:97-8) discussion of this issue. In this context, it is worth noting that the Dutch word tent can refer to a canvas tent, in the English sense, or be used as a generic term denoting a non-permanent structure, such as a shed or a barn. It is also a colloquialism for referring to an establishment, in the same sense as the English term 'joint' or 'place'. The term bamboetent, used to describe many of the (more or less) 
times per day, with film programmes changing twice per week, meaning that a steady stream of films was required in order to keep up and sustain cinema's appeal to returning audiences. ${ }^{18}$ Just a couple of years later, modern cinemas built out of brick and stone began to pop up in various town squares. Patrons of these venues were able to purchase food and drink as well as cigarettes and rolling tobacco, whether in buffets provided by the cinema entrepreneurs or in independent warung (kiosks) just outside. And while 'native dandies' wore the white clothing traditionally associated with Westernized dress, as suggested in the opening quote of this article, it was apparently not uncommon to find audiences wearing a 'fez or Mohammedan skullcap', colourful headscarves and other variations of Native dress (Fromberg 1914:23).

In light of the supposedly neat division into European and Native sections, it is difficult to establish where the Chinese fitted into this layout. Yet, since many of the owners of exhibition venues and film companies on Java were themselves Chinese, and given that many of the Chinese traders were the wealthiest residents of the colony, we can safely assume that they were welcome visitors in the cinemas and, presumably, would have been seated in the so-called European section. And while for several decades the Chinese were restricted in terms of travel, and further subjected to strict zoning in urban areas by Dutch government regulations wishing to control their commercial activity, by 1904 such restrictions had been significantly relaxed and mobility was facilitated. ${ }^{19}$ As mentioned above, sometimes separate tickets were offered to Foreign Orientals, which at times specified those of Chinese and Arab descent, in which case these ticketholders would probably have been seated in the second or third

permanent, early moving-picture venues in the Indies is thus rather effective at capturing the transient permanence of many of these structures.

18 According to a report from 1907, in that year alone there were 35 companies on Java offering moving-picture shows, whether as travelling outfits or more stationary exhibitors (Nieuwe Soerabaja Courant, 16-8-1907). This research was able to identify by name 23 different companies showing moving pictures on Java in 1907, and several others which remain unidentified. Since there are surely other companies that were missed or not reported about in the newspapers, the Nieuwe Soerabaja Courant's estimate of 35 touring companies appears reasonable.

19 The 1863 passenstelsel (pass system) regulations were at times upheld so strictly that in the late nineteenth century 'it became necessary for Chinese to get new visas for every four days spent away from home. A pass was required for short trips, such as the one from Batavia to Meester Cornelis, only an hour's journey even in 190o' (Williams 1960:30). Those travelling without a pass, or with a fake document, risked fines and imprisonment. As of 1904, travel passes were issued for a one-year period rather than a single journey (Claver 2014:188). 


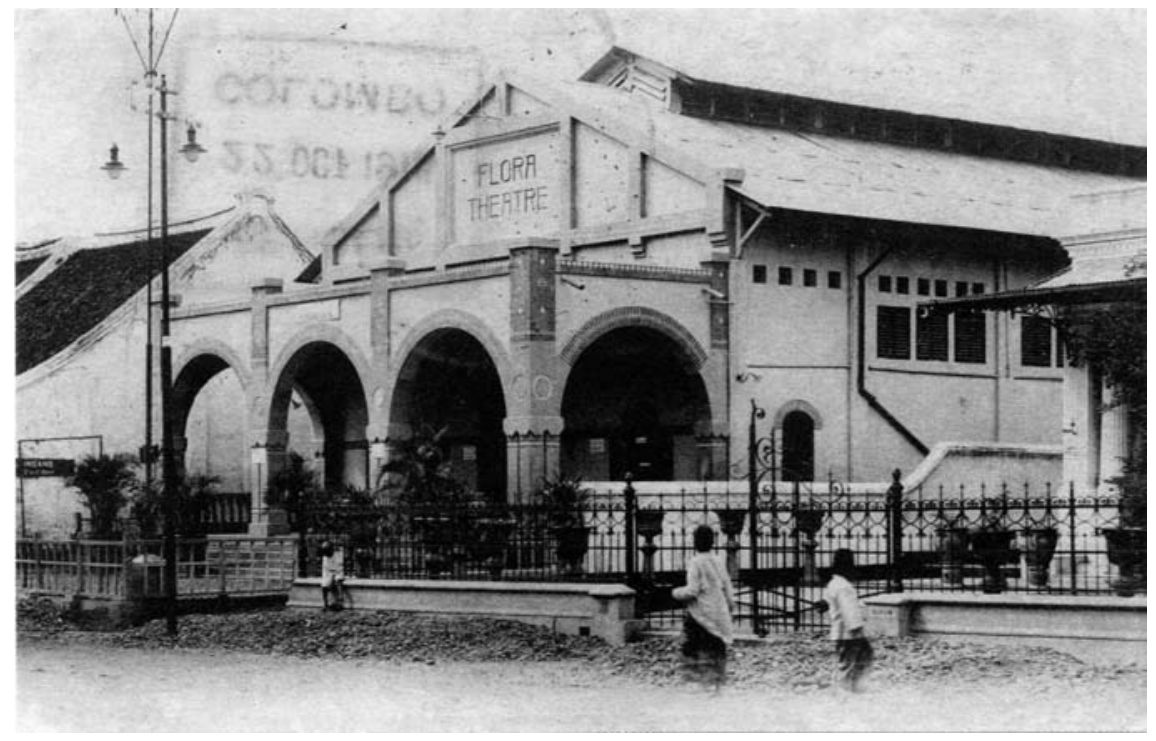

FIGURE 6 Image of the West-Java Bioscope at the Flora Theatre, in which a sign is visible indicating that the entrance to the lower ranks of seating was separate. Picture postcard, postmarked 21 January 1920.

GREETINGS FROM JAKARTA (C) SCOTT MERRILLEES AND EQUINOX PUBLISHING JAKARTA

class on wooden stools or benches in front of the screen, while the fourth class for Natives would have sat on the ground or on bamboo mats behind the screen.

Another group that problematizes the layout of the space is the Indonesian native elite class. For instance, at a venue in Surabaya in 1909, the section for the Native class of audiences was split into two: one area was intended for the Indonesian elite, while the other was for the 'Native coolies', since the former did not wish to be seated next to the latter (Nieuwe Soerabaja Courant, 10-91909). It is not clear whether in this case the sections for Natives were directly in front of the screen or behind it (see Fig. 6 of the Flora Theatre in Batavia, in which a sign is visible indicating that entrance to the lower ranks of seating was separate from the main entrance). Either way, for the most part it appears that if Native or Chinese audiences were able and willing to spend more money on a cinema ticket, they would not have been barred from entering other sections of the cinema. ${ }^{20}$ As Cohen (2006:132) found in the komedi stambul, whoever

20 To give an example from a slightly later period: according to Rudolf Mrázek's (2010:118) interviews with members of the Indonesian elite class who grew up in Batavia in the 1920 and 1930s, one self-proclaimed cinema-going buff talked about the first time his 
could afford to pay was able to sit wherever he (or she) chose to sit. In light of the population statistics and the number of seats in moving-picture venues, which often accommodated about 1,500 audience members, we can assume that the situation was similar among cinema entrepreneurs who were out to make a profit. Thus there is a clear case here of the boundaries between race and class being blurred.

\section{'Come on Wifey, Don't Get Wound Up': Gender and Audiences}

It is difficult to estimate the percentage of women-of any ethnic or class group-among cinema-goers in turn-of-the-century colonial Java. Since many venues for moving-picture shows were stationed in close vicinity to military garrisons or on grounds owned by the military, with exhibitors offering discounts or even a certain number of free tickets per month to soldiers, it is safe to assume that the vast majority of audience members at moving-picture shows were male. ${ }^{21}$ Nevertheless, women were definitely part of the moving-picture business, as consumers, owners, or exhibitors, ${ }^{22}$ and later also as film cen-

father took him to a cinema, when he was eight years old, and about being seated in the prestigious box seat. The only instance found in this research of restrictive policies was at a touring show held in Medan, when Natives were initially banned from attending the International Bioscope's shows. The policy was changed after a couple of shows, but the box seats were still off limits to Native audiences (Sumatra Post, 7-8-19o9). We can only assume that such restrictions were applied in other cases, too.

21 Cinema owners offered discounts only to soldiers below the rank of officer. It should be noted that an audience made up of male soldiers would have been homogeneous in terms of gender, but would have simultaneously represented a heterogeneous mixture of ethnicities. The Koninklijk Nederlands Indisch Leger (Royal Netherlands Indies Army) was not exclusively made up of Dutchmen, but consisted also of other European recruits (mostly German). The majority of soldiers were recruited among the Indonesian population, mainly from Java and the Moluccas (Teitler 2006).

While the only female exhibitor identified in this research was Miss Meranda, I take this as a sign that there must have been other women involved in exhibition of moving images. Some exhibitors travelled with their wives, who were also incorporated into the shows, as in the case of Emily D'Alton, the wife of Carl Hertz. Other women were involved on the management side; for instance, after the death of her husband in 1893, Jane Harmston Love managed Harmston's Circus together with her second husband, Robert Love (see Tofighian 2013:121). According to the establishment documents of the Venus Cinema Theatre in Tegal in 1913, another widow by the name of Emelie Anna Damme (née Straub) from Semarang was the co-founder and co-owner of the cinema, alongside Mr. Dirk van Vianen (Extra-Bijvoegsel der Javasche Courant 18/4-1913, no. 31). 
sors. ${ }^{23}$ The fact that various companies offered a special 'gentlemen's programme' at the conclusion of the standard evening show, with more risqué films featured once women (and children) had left the premises, is in itself an indication that, even though proprietors saw adult, male audience members as their primary target market, women were regularly part of the cinema audience. Moreover, it plainly shows that there were certain images that were deemed inappropriate for women to watch, whatever class or ethnic affiliation they belonged to, especially in a shared viewing situation with men of various ethnicities.

The patronizing of women audience members did not end there. Several screenings described at length in the newspapers suggest that women were perceived as irrational or childish audience members, reminiscent of the enduring myth of the first audiences in the West running away from the screen at the sight of an arriving train. ${ }^{24}$ For instance, as further described by the abovementioned Surabaya reporter in 'An evening at the Biograph':

During the scene of a fire that also impresses the natives, a nervous lady is startled and says excitedly to her husband: 'Good man, if there were a fire here now ... at our home ... our baby ... I'm going home ... I'm leaving, leaving!' The man tries to calm her down, 'Come on wifey, don't get wound up, nothing is happening', but the anxious mother already has one foot out of the tent.

Soerabaiasch-Handelsblad, 25-11-1904

Such moralizing and condescending attitudes point to some of the challenges presented by the sources used here, which were written mostly by European, Eurasian, or Javanese male authors. Keeping these points in mind, this section nevertheless strives to offer a glimpse into women's early cinema-going habits on Java.

23 European women were sought after as potential volunteers for the censorship committees set up in the 1910s. Having plenty of free time on their hands and perceived as strict and meticulous, it was expected that the censorship process would particularly benefit from European women's involvement (Sumatra Post, 25-9-1918). However, another report cautioned against employing too many 'old spinsters' to perform the task, as this would run the risk that the resulting censorship system would be far too scrupulous (Sumatra Post, 24-4-1918).

24 This founding myth of the cinema has been questioned by various scholars of early cinema; see Bottomore 1999; Gunning 1995; Loiperdinger 2004. 
The arrival of moving pictures in colonial Java coincided with changes in the make-up of the European population, mostly as a result of the lifting of certain restrictions on the immigration of, and marriage to, women from the Netherlands, as well as a lower tolerance of concubinage arrangements between Europeans and their Indonesian housekeepers (nyai). During the first quarter of the twentieth century, Locher-Scholten (2000:122) writes, the European population of the colony rapidly expanded, with the sex ratio changing from more than 600 women per 1,00o men in 1900 to nearly goo per 1,000 in 1930. Dutchborn women (totok) especially accounted for the growing ratio of young, educated, European women residing in Java's urban centres. ${ }^{25}$ Locher-Scholten (2000:123) continues, 'More than half of all European women and two-thirds of totok women lived in one of the "big six" cities of Java', and they were by and large married. These are noteworthy figures to consider when thinking about cinema attendance in Java's urban centres.

As part of an attempt by exhibitors of moving pictures to market their business as a modern, family-friendly entertainment form, promotional articles and advertisements for moving-picture shows, appearing in both the Dutch and Malay newspapers, repeatedly appealed to married men by calling on audiences to attend moving-picture shows with their wives and children. Exhibitors offered discounts in the higher-paying first- and second-class seats to men attending with their spouses, as well as half-priced tickets to children below the age of ten in the same pricing tier. European women in the cities thus ostensibly attended the cinema accompanied by their husbands, and possibly, their children. ${ }^{26}$ Considering there were still various arrangements of marriage across racial lines, this policy would have equally brought Indonesian and Eurasian women to the cinemas with their partners. Higher-class Chinese audiences would have also benefitted from such discounts.

25 The number of totok women rose from 179 per 1,00o men in 1900 to 582 per 1,00o in 1930 . In the words of Locher-Scholten (2000:123): "The majority were between 20 and 50 years of age and busy building a career. Totok, expatriates with high levels of education, dominated this group. In the older age groups the totok representation declined to 30 percent. Totok women remained a minority in all age groups, although in the 30-39 age bracket totok women were nearly equal in number to European women born in the Indies. Because of the age difference between men and women in European marriages in the Indies, there were few totok women above the age of 60 in the Indonesian archipelago. By this age they had generally returned to the metropole.'

26 For example, Governor General Van Heutsz reportedly attended a special screening of the Royal Bioscope in Batavia with his wife and two children (Taman Sari, 29-12-1905). 
Several reports over the period of this research suggest that Chinese women were also to be found in the audience, and in a greater number whenever the venue was located in a part of town associated with the Chinese. It appears that wealthy Chinese women dressed up to go to the cinema, as can be inferred from the jewellery occasionally reported as lost or found at venues. For example, a Chinese woman attending the Globe Bioscope in Batavia's Pasar Baru complained that, upon leaving the cinema, her diamond pin was stolen by a 'Native' (Het Nieuws van den Dag voor Nederlandsch-Indië, 10-4-1909). In yet another case, a golden bracelet was found at the same venue and the owner was invited to retrieve it at the police station (Het Nieuws van den Dag voor NederlandschIndië, 14-8-1911). ${ }^{27}$ Class, once again, played a role in these women's cinemagoing experiences. At one venue in Batavia's Kongsi Besar, several Chinese women - either attending with their husbands or on their own-were inappropriately groped by an 'Indo-European' employee when entering the cinema tent (Soerabaiasch-Handelsblad, 4-7-1905). But it was only when the wife of a wealthy Chinese man suffered the same treatment that an uproar erupted and a boycott of the venue was proclaimed.

While no price reduction was normally offered to couples or families in the Native sections of the audience, many Javanese women similarly attended with their husbands and children, as evidenced from newspaper descriptions of moving-picture shows throughout the period. Other Javanese women presumably attended with their own children, or as minders of the European children in their charge, judging by the advertisements for afternoon children's programmes that offered tickets to chaperones at a discount.

To what extent women were at liberty to enter the cinemas on their own remains unknown. As observed in the opening quote of this article, it was feared that young women attending the cinema would flirt with men, possibly of another class or ethnic group to their own, and were even at risk of running off with them. Several venues on Java, identified as targeting the nonEuropean population, seemed to cater to such concerns of mixing by practising a gender-based separation of the cinema audience, with advertisements stating that men and women would be seated separately (see, for example, Kabar Perniagaan, 24-2-1905; Bintang Batavia, 21-9-1905; Taman Sari, 28-11-1905). ${ }^{28}$ And

27 Bicycle thefts from outside the cinema tents were quite common as well (Het Nieuws van den Dag voor Nederlandsch-Indië, 14-12-19o8).

28 In some regions where Islam was more prominent, gender-based separation of the audience appears to have occurred also in 'mixed' cinemas, presumably enforced only in the section for Natives (Deli-Courant, 6-8-1909). 
while numerous 'gentlemen's programmes' were advertised, only one example of a 'ladies only' show, offered by the Java Cineograph in Yogyakarta in late 1901, was found in this research (Het Centrum, 7-12-1901). The show, performed at seven o'clock on a Sunday evening and priced at $f$ 1.oo per ticket, followed two consecutive nights of a 'gentlemen's programme', performed at half past nine in the evening on Friday and Saturday and priced at $f 2.50$ and f1.50, respectively (Het Centrum, 6-12-1901 and 7-12-1901). The 'gentlemen's programme', according to coloured leaflets scattered around the city and picked up by schoolchildren, included scandalous scenes of 'adultery, the nude model of a painter, [and] scenes from the Moulin Rouge' (De Locomotief, 12-12-1901). ${ }^{29}$ Unfortunately, no revealing details about the content of the 'ladies only' show were found. Having uncovered just a single example surely means that more screenings for women only were performed, yet it also shows that targeting women specifically as audiences was not prevalent among early movingpicture exhibitors.

\section{'Chinese and Natives Especially Love Such Amusements': Film Programmes' Challenge to Colonial Order}

The content of film programmes deserves particular attention, especially since various films challenged traditional ideas about race, class, and gender in colonial society, even if contemporary commentators seemed oblivious of their potential for arousing dissent. For example, a description from a screening in Sukabumi of scenes depicting the Russo-Japanese War, the 1904-1905 conflict that saw the Japanese succeed in vanquishing the Russian Imperial Army in the Far East, gives a good sense of the atmosphere:

The Royal Bioscope always draws large crowds with its shows. Chinese and natives especially love such amusements and of course the favourite topic of such spectacles: the Russo-Japanese War. On war evenings, as we shall call them, it was packed and with every new Japanese victory came a loud applause.

Het Nieuws van den Dag voor Nederlandsch-Indië, 14-12-19o4

29 The schoolchildren reportedly 'made themselves merry over the scenes that daddy would get to see in the evening' (Sumatra Post, 25-9-1918). 
Surprisingly, no commentator of the day seemed to view the Native and Chinese audience members' enthusiastic cheering of the Japanese naval victories as potentially problematic.

Contemporary commentators generally tended to veer between the cinema's pedagogical possibilities of modernizing its audiences, as expressed in films showing modern living conditions, industry, and progress, and the potentially negative education in the so-called modern manner involved in watching detective or crime films (Nieuw Soerabaja Courant, 10-2-1910). ${ }^{30}$ For instance, when in 1914 the Resident of Surabaya prohibited the screening of any film in which a European person was 'abused, injured or killed by Natives, Foreign Orientals or Indians', effectively banning most detective, cowboy, and war films, a lengthy article on 'Morality and the cinema' in Soerabaiasch-Handelsblad debated such nanny-state measures (Soerabaiasch-Handelsblad, 23-3-1914). On the one hand, it discussed how the ban could help improve the morality in the Indies, of Europeans and Natives alike, since they were all drawn to such 'sensational films'. On the other hand, it explained that if the ban was implemented, then the profitability - for exhibitors and the municipality-would fall because the Natives, who arguably formed the majority of cinema audiences, would no longer go to the cinema. It would therefore also constitute a missed opportunity for the potential education of the Natives. 'After all', the article claimed,

all [Westerns], without exception, end in favour of the whites, while the rebellious Indians are usually also punished at the final dramatic climax. There is nothing harmful [...] about these films; on the contrary, the Natives cheer loudly, expressing their joy when the whites prevail as always. In this cheering is [expressed] a certain skill to deduce what feels right, and certainly these cheers would not be heard if the Indians were the victorious party.

30 Thieves in the big cities were allegedly being 'modernized by the cinema' (Bataviaasch Nieuwsblad, 15-1-1912). The connections drawn to crime and unrest made the need to police and control moving-picture shows increasingly pertinent. Such anxieties about the corrupting power of cinema are reminiscent of parallel discussions in the West. According to Grieveson's (2004:14) work on film censorship in the United States in the early twentieth century, cinema as 'a school for crime' was a common trope, consequently making it 'subject to increasingly intense public discussions and governmental interventions'. Moving pictures were often linked with legislative 'discourses on youth, class, ethnicity, gender, urban unrest, and modernity' (Grieveson 2004:15). 
Since the Natives cheer when the white man defeats the Indians, the article proposed, they presumably know the correct order of things. Westerns are thus interpreted here as reinforcing the colonial order.

Such comments echoed earlier concerns surrounding the decision by the assistant-resident of police in Batavia to prohibit the screening of films showing 'murders, robberies, adulteries, and muggings' in 1912 (De Locomotief, 5-7-1912). The Batavia correspondent for De Locomotief then noted that if 'sensational films' were no longer to be shown, audiences would be deprived of the big attraction that draws them to the cinema, and therefore cinemas would be robbed of their income (De Locomotief, 10-7-1912). The article further expressed serious doubts about the logic behind this decree, arguing that if the crime shown in the film was punished, as happened in most cases, then one could argue that these films had a pedagogical value. The correspondent further questioned the notion that so-called 'sensational films' had any effect on crime levels:

Now I can still remember very well the time when there were no cinemas, so no thrilling films existed in Java. And ever since, not much has changed in Java, at least not in Batavia. The general development of the natives and the other Orientals is largely unchanged, not significantly improved. The police have remained virtually the same; until recently very few advancements could be found. The social conditions, the living conditions of people are almost the same. Therefore, one can safely conclude that if these sensational films were actually that dangerous, this would have necessarily been expressed in an increased number of crimes, and overall everything has remained the same.

Moreover, the reporter emphasized the potential educational value of cinema, especially for Native audiences: 'the little man can obtain a lot of knowledge which, in his circumstances, he would not be able to get in any other way. He sees other countries, other peoples, other customs and traditions. He is taken out of the small circle of his kampoeng and a large, new, never-thought of world is opened up to him.'

One topic that officials and newspapers seemed to be in agreement on was the representation of European women. How European women were presented on screen and could be perceived by 'eager Native and Chinese eyes' was a concern, especially in films showing a 'white beauty' intimately kissing and hugging, 'reviving in front of the appraising eyes of Kromo and John Chinaman images that must give the Native a most peculiar peek at our civilized European life ... of our European women' (De Locomotief, 2-4-1912). Many such comments 
in various cities were made specifically about Asta Nielsen films, the biggest international film star of the day, who was one of the 'cinema darlings' of 'the Chinese, the Malays and the Javanese. ${ }^{31}$ Moreover, it was not only the films' contents, but also the way in which they were advertised that raised anxiety levels. For instance, a 'garish coloured plate, depicting an episode from a San Francisco morality drama in which a Chinese is shown at work with the clearly dishonourable intentions of stabbing a fashionably dressed European lady' was depicted on a sandwich board in Surabaya in 1912 (De Locomotief, 4-9-1912). 'Anyone who acknowledges the suggestive power that emanates from such a representation', De Locomotief advocated, 'will undoubtedly have to recognize that such advertising boards and such films should not be tolerated here'.

Even content that was supposedly deemed safe, such as moving pictures of Queen Wilhelmina's investiture in 1898 , proved to be problematic. At times, the reception of such images supported an idyllic notion of a unified colonial society, with audiences of all ethnicities applauding and cheering the queen together. 'One can imagine how the soldiers, white and brown, were elated', Albrecht's Zondagsblad reported, about a screening for a mixed audience of Native and European soldiers in Batavia:

Though during the days of September 1898 they were striking in Pedir, ${ }^{32}$ they now had the chance to see it at least as well as the Amsterdammers! The Javanese knew Her Majesty only from a still portrait, and now, thanks to this wonderful invention, it was as if she appeared in front of them in flesh and blood.

Albrecht's Zondagsblad, 14-5-1899

Similar to Benedict Anderson's understanding of the advent of print capitalism as helping to form an 'imagined community' among people who have never encountered each other in person, the multi-ethnic residents of the Indies were perceived as patriotically banding together at the sight of mechanically reproduced moving images of their monarch. ${ }^{33}$ However, at another screening of similar images in Surabaya, students from the Dutch-run secondary school insolently stood up in the front seats, blocking the view of those in the more expensive seats at the back (Soerabaiasch-Handelsblad, 18-9-1899).

31 De Kinematograaf 1-35 (1913), p. 254. For more on Asta Nielsen films in the Indies, see Ruppin 2013.

32 A punitive expedition that was part of the Aceh War.

33 See also Tofighian's (2013:217-24) discussion of the screenings of Queen Victoria's jubilee celebrations and Singapore and other British colonies in Southeast Asia. 
Further accompanying the images with whistling and screaming, the colony's future 'cultural citizens' thus revealed the cracks that were forming in colonial society. ${ }^{34}$

\section{Concluding remarks}

In turn-of-the-century colonial Java, new technologies for projecting moving images, along with the latest films on offer, often arrived in far-flung locations within just a matter of weeks from their first appearance on screens in the West. Modern cinema theatres in cities across Java further gave urban dwellers a sense that they were up to date with developments in other parts of the globe when it came to the consumption of this modern form of entertainment. Contemporary commentators on Java certainly realized that they were witnessing, and actively participating in, the international advent of moving pictures. And, as long as films' educational value outweighed their potential to disrupt the colonial status quo, the colonial authorities by and large took a laissez-faire attitude - even when Native and Chinese audiences cheered at the sight of Japanese naval victories over the Russians. Most pre-First World War commentators agreed that in many, if not most, cases, film

can be regarded as a living newspaper which brings forth all the news and modern things in the fields of industry, art, and ethnography. People of this land, who may never witness Western conditions, are imparted here with an idea of European and American life. In this respect, the cinemas are very educational and useful.

Nieuwe Soerabaja Courant, 10-2-1910

Thus, similarly to the 'cultural citizens' who were the target audiences of advertisements in Schulte Nordholt's work, audiences were exposed to modern things and desirable lifestyles on screen by going to the cinema and learning about other places and cultures. At Java's cinemas, 'cultural citizenship' as an invitation to abandon traditional ways of life was not the sole preserve of Europeans or indigenous elites, but open to cinema-goers from all levels of colonial society. The ability to purchase a cinema ticket and spend one's leisure time at

34 By the 1940s, according to Mrázek (2002:111), colonial officials were recording Indonesian audiences raising a ruckus while images of Queen Wilhelmina were being projected on screen, and even while the Dutch national anthem was being played. 
the cinema gave audiences an illusion of equality and, in turn, served to reinforce the objectives of the colonial authorities in executing the Ethical Policy: educating and uplifting the Natives from their present conditions by exposing them to scenes depicting European and American lives through the medium of moving images. Once education at the cinema was perceived by the authorities as instruction in the wrong kind of 'modernity', such as the strong racial underand overtones found in detective or crime films, there was a shift towards anxieties about cinema's negative effects on Native audiences. Initially left at the hands of the local police in each province and municipal authority, leaving an opening for many dissenters, control of moving-picture shows became tighter and increasingly regulated, with more directives emanating from the Governor General as of 1912. Nevertheless, official censorship would only be introduced with the 1916 Bioscoopordonnantie (Bioscoop Ordinance) (see Ruppin 2016; Berg 1992).

Finally, 'cultural citizenship' at Java's cinema houses was imbued with the class and racial hierarchies of colonial society through the separation between the different classes of audience: whether by relegating the so-called Native section to the space behind the screen or locating it in the front rows known as the kambing (goat) class. At times, separation along gender lines also occurred at certain venues, and otherwise the patriarchal order was generally reinforced by encouraging men and women to attend the cinema together, or even as a family. And while the audience members of the komedi stambul, circus, or earlier tent shows for moving pictures could jump seats to secure a better viewing spot and mix with other sections, it is difficult to imagine how Native audiences at Surabaya's cinema of the East Java Bioscope could emerge from behind the screen. Nevertheless, as Rudolf Mrázek (2002:13) writes about the experience of riding the trains in the Indies, even though there were separate cars for each class of passengers, 'the rhythm of the train, the shaking, and the machine were the same. All the passengers were (travelling) humans, and their uncomfortable sameness could nowhere be seen, felt, and smelled as strongly as in the train'. While the comfort level in the cinema was similarly stratifiedin terms of access and seating comfort-all audience members, seated in the dark, could be transported together to another world, thanks to the images they were watching on screen, which were projected from the same flickering device. Audiences' engagement with modernity at the cinema in colonial Java was thus classed, racialized, and gendered; yet, despite the fact that they often could not see each other, they could still hear and smell each other. Just like the visitors to the public fairs as depicted in Arnout van der Meer's contribution in this issue, and despite attempts to maintain racial and gender divisions, which were becoming more complicated as class distinctions tended to interfere, 
audiences from all levels of colonial society were brought together at Java's cinemas to share the same experience of watching modernity on screen.

\section{References}

Abdullah, Taufik, Misbach Yusa Biran and S.M. Ardan (1993). Film Indonesia. Bagian I (1900-1950). Jakarta: Perum Percetakan Negara RI.

Abel, Richard (ed.) (2005). The encyclopedia of early cinema. London: Routledge.

Abel, Richard (2012). 'Early film programs: An overture, five acts, and an interlude', in: André Gaudreault, Nicholas Dulac and Hidalgo Santiago (eds), A companion to early cinema, pp. 334-59. Malden, MA and Oxford: Wiley-Blackwell.

Anderson, Benedict (2006 [1983]). Imagined communities: Reflections on the origin and spread of nationalism. Revised ed. London and New York: Verso.

Ardan, S.M. (2005). 'Indonesia', translated by Raymond Edmondson, in: Richard Abel (ed.), Encyclopedia of early cinema, p. 320. London: Routledge.

Berg, Soeluh van den (1992). 'Notabele ingezetenen en goedwillende ambtenaren: De Nederlands-Indische filmkeuring, 1912-1942', in: Jaarboek Mediageschiedenis 4: Nederlands-Indië, pp. 145-71. Amsterdam: Stichting Mediageschiedenis.

Biltereyst, Daniel, Richard Maltby and Philippe Meers (2012). 'Cinema, audiences and modernity: An introduction', in: Daniel Biltereyst, Richard Maltby and Philippe Meers (eds), Cinema, audiences and modernity: New perspectives on European cinema history, pp. 1-16. London: Routledge.

Biran, Misbach Yusa (2009). Sejarah film 1900-1950: Bikin film di Jawa. Jakarta: Komunitas Bambu.

Bottomore, Stephen (1999). 'The panicking audience?: Early cinema and the "train effect"', Historical Journal of Film, Radio and Television 19-2:177-216.

Bottomore, Stephen (2005). 'Malaya', in: Richard Abel (ed.), Encyclopedia of early cinema, pp. 590-1. London: Routledge.

Claver, Alexander (2014). Dutch commerce and Chinese merchants in Java: Colonial relationships in trade and finance, 1800-1942. Leiden: Brill.

Cohen, Matthew Isaac (2006). The komedie stamboel: Popular theater in colonial Indonesia, 1891-1903. Leiden: KITLV Press.

Colombijn, Freek, with the assistance of Martine Barwegen (2010). Under construction: The politics of urban space and housing during the decolonization of Indonesia, 19301960. Leiden: KITLV Press.

Cooper, Frederick (2005). Colonialism in question: Theory, knowledge, history. Berkeley: University of California Press.

Coulter, Harold G. (1909). 'The kinematograph in the East', The Kinematograph \& Lantern Weekly:1039. 
Fasseur, C. (1994). 'Cornerstone and stumbling block: Racial classification and the late colonial state in Indonesia', in: Robert Cribb (ed.), The late colonial state in Indonesia: Political and economic foundations of the Netherlands Indies 1880-1942, pp. 31-56. Leiden: KITLV Press.

Fromberg, P.H. (1914). 'De Inlandsche beweging op Java', De Gids 78:23.

Furnivall, J.S. (2010 [1967]). Netherlands India: A study of plural economy. Cambridge: Cambridge University Press.

Grieveson, Lee (2004). Policing cinema: Movies and censorship in early-twentieth-century America. Berkeley: University of California Press.

Gunning, Tom (1995). 'An aesthetic of astonishment: Early film and the (in)credulous spectator', in: Linda Williams (ed.), Viewing positions: Ways of seeing film, pp. 114-33. New Brunswick: Rutgers University Press.

Khusyairi, Johny A. and Freek Colombijn (2015). 'Moving at a different velocity: The modernization of transportation and social differentiation in Surabaya in the 1920s', in: Freek Colombijn and Joost Coté (eds), Cars, conduits, and kampongs: The modernization of the Indonesian city, 1920-1960, pp. 251-71. Leiden and Boston: Brill.

Locher-Scholten, Elsbeth (2000). Women and the colonial state: Essays on gender and modernity in the Netherlands Indies 1900-1942. Amsterdam: Amsterdam University Press.

Loiperdinger, Martin (2004). 'Lumière's arrival of the train: Cinema's founding myth', translated by Bernd Elzer, The Moving Image 4-1:89-118.

Maltby, Richard (2011). 'New cinema histories', in: Richard Maltby, Philippe Meers and Daniel Biltereyst (eds), Explorations in new cinema history: Approaches and case studies, pp. 3-40. Oxford: Wiley-Blackwell.

Mrázek, Rudolf (2002). Engineers of Happy Land: Technology and nationalism in a colony. Princeton: Princeton University Press.

Mrázek, Rudolf (2010). A certain age: Colonial Jakarta through the memories of its intellectuals. Durham: Duke University Press.

Pleyte, Cornelis Marinus (1907). Verslag nopens de Pasar Gambir gehouden op het Koningsplein te Weltevreden van 28 Augustus-2 September, 1906. Batavia: Landsdrukkerij.

Ruppin, Dafna (2013). 'Asta Nielsen, cinema-going and film censorship in the Netherlands-Indies, 1912-1918', in: Martin Loiperdinger and Uli Jung (eds), Importing Asta Nielsen: The international film star in the making 1910-1914, pp. 299-307. New Barnet: John Libbey.

Ruppin, Dafna (2016). The komedi bioscoop: Early cinema in colonial Indonesia. New Barnet: John Libbey.

Schulte Nordholt, Henk (2015). 'Modernity and middle classes in the Netherlands Indies: Cultivating cultural citizenship', in: Susie Protschky (ed.), Photography, modernity and the governed in late-colonial Indonesia, pp. 223-54. Amsterdam: Amsterdam University Press. 
Setijadi-Dunn, Charlotte and Thomas Barker (2010). 'Imagining "Indonesia": Ethnic Chinese film producers in pre-independence cinema', Asian Cinema 21-2:7-24.

Shiraishi, Takashi (1990). An age in motion: Popular radicalism in Java, 1912-1926. Ithaca: Cornell University Press.

Stein, Eric A. (2006). 'Colonial theatres of proof: Representation and laughter in 1930 s Rockefeller Foundation hygiene cinema in Java', Health \& History 8-2:14-44.

Stoler, Ann Laura (1989). 'Making Empire respectable: The politics of race and sexual morality in 2oth-century colonial cultures', American Ethnologist 16-4:634-6o.

Teitler, Gerke (2006). 'The mixed company: Fighting power and ethnic relations in the Dutch Colonial Army, 189o-1920', in: Karl Hack and Tobias Rettig (eds), Colonial armies in Southeast Asia, pp. 146-6o. London and New York: Routledge.

Tofighian, Nadi (2013). Blurring the colonial binary: Turn-of-the-century transnational entertainment in Southeast Asia. [PhD dissertation, Stockholm University, Stockholm.]

Vickers, Adrian (1996). 'Modernity and being moderen: An introduction', in: Adrian Vickers (ed.), Being modern in Bali: Image and change, pp. 1-36. New Haven: Yale University Southeast Asia Studies.

Williams, Lea E. (1960). Overseas Chinese nationalism: The genesis of the pan-Chinese movement in Indonesia, 1900-1916. Glencoe: The Free Press.

\section{Filmography}

Méliès, Georges (1902). Voyage dans la lune. Star Film Company. 